\title{
Investigation on the Diode Temperature-Sensor with the Output Voltage Proportional to the Absolute Temperature
}

\author{
Noriaki Takashima Student Member (Tohoku Gakuin University) \\ Mitsuteru Kimura Member (Tohoku Gakuin University, kimura@tjcc.tohoku-gakuin.ac.jp)
}

Keywords : temperature-sensor, pn diode, semiconductor, $\mathrm{Si}$, proportional output to the temperature, AC signal

Many researches on sensor devices integrated together with plural functions have been reported as miniturizing sensors and advancing the performance of microcomputer. Sensor devices with highly packed microwave circuits to communicate with another nodes, which are acting as a node in the sensor net-work and have many functions of physical sensing such as the temperature and the magnetic field, have been proposed. Especially in the medical use, highly functional and miniaturized wireless sensors directly introduced to the body to reduce the patient's load and to make high quality medical care have been reported. In this paper a new measurement method to conventionally measure the temperature is proposed and demonstrated. Thermistor and thermodiode are very familiar as an absolute temperature-sensor. However the thermistor has a narrow measurable temperature range as a single temperature-sensor and has a non-linear relationship between the temperature $T$ and the output voltage.

As to the thermodiode they have a linear dependence between the forward voltage and the absolute temperature $T$ under a fixed forward current $I_{0}$. However, it needs the off-set balance control of the OP-amp in order to amplify the dc signal.

Our temperature-sensor uses only a single pn junction diode and it is unnecessary to control the off-set voltage. It uses a superimposed small ac current $\delta I$ to the dc forward constant current $I_{0}$ and pickup the ac output voltage $\Delta V$ using the dc-cut capacitor connected to the pn junction diode as a temperature-sensor. It can measure the wide temperature range 77 $-470 \mathrm{~K}$ and has the output voltage theoretically proportional to the absolute temperature $T$. In addition, it has merits that the calibration of our temperature-sensor should be theoretically done at only one temperature point and that thermometry of a very small area can be achieved because of a simple and very small sensing probe of the pn junction diode.

Generally forward biased current $I$ of a pn junction diode is expressed as a following equation.

$$
I=I_{s}(T)\left\{\operatorname{Exp}\left(\frac{q V_{F}}{n k T}\right)-1\right\} \approx I_{s}(T) \operatorname{Exp}\left(\frac{q V_{F}}{n k T}\right) .
$$

Differentiating this equation (1) by $V$, changing it into an expression to the absolute temperature $T$, putting de current $I$ with constant value $I_{0}$ and rearranging $d I / d V$ in $\Delta I / \Delta V$ for output signal or $\delta I / \delta V$ for superimposed signal, therefore we can get a following equation,

$$
T=\frac{q}{n k} \frac{I_{0}}{\delta I} \Delta V=\alpha \Delta V
$$

The above equation (2) means that the absolute temperature $T$ is proportional to the amplitude of this $\Delta V$. Therefore, we should determine the fixed value $\alpha$ in equation (2) at a single temperature point. We can achieve an extremely simple thermometer displaying the absolute temperature $T$.

In Fig. 1 the block diagram of the measurement circuits for the proposed method is shown.

We have used a commercial high speed Si pn junction diode to verify the theory, because it is unnecessary to use special diodes. In our experiments, we put the dc current $I_{0}=1000 \mu \mathrm{A}, \delta I=30 \mu \mathrm{A}$ (for both sine and square waves) and $f=1 \mathrm{kHz}$. Temperature $T$ output voltage $V_{0}$ characteristics of the commercial Si diode is shown in Fig. 2. We can see from this Fig. 2 that the relationship between the output voltage $V_{0}$ and the absolute temperature $T$ has almost linear dependence in the temperature range between 77 and $470 \mathrm{~K}$ as the theory expressed in equation (2) for both sine and square waves. Errors in linearity of chracteristics of the output voltagae $V_{0}$ vs. absolute temperature $T$ were within $3 \%$ and $6 \%$ in measured temperature ranges of $100-320 \mathrm{~K}$ and $77-470 \mathrm{~K}$, respectively. In actual use it will be easier to fix the amplitude of $\delta I$ for the square wave than the sine wave.

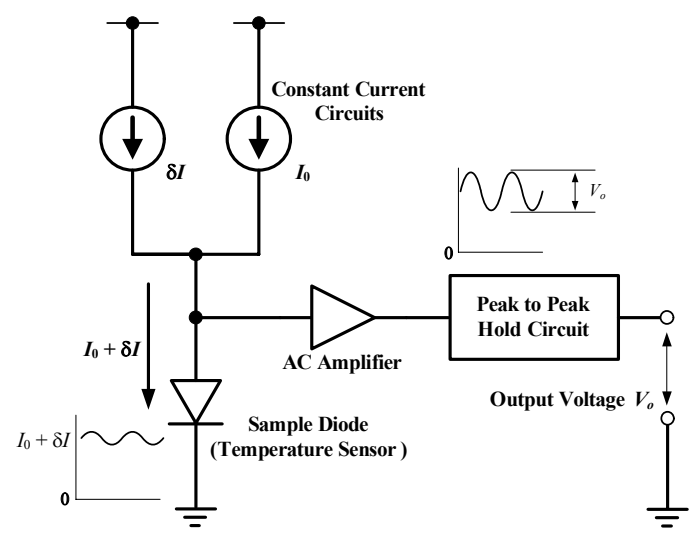

Fig. 1. Block diagram of the measurement circuits for our proposed method

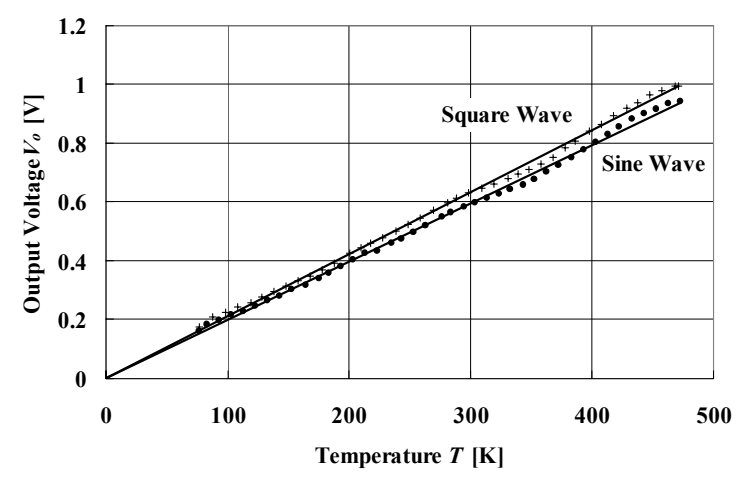

Fig. 2. Temperature $T$ - output voltage $V_{0}$ characteristics using sine and square wave as the $\delta I$ 


\begin{abstract}
絶対温度に比例する出力を持つダイオード温度センサの検討

\author{
学生員 高嶋 徳明* 正 員 木村 光照* \\ Investigation on the Diode Temperature-Sensor \\ with the Output Voltage Proportional to the Absolute Temperature \\ Noriaki Takashima*, Student Member, Mitsuteru Kimura*, Member
}

A new method to obtain the output voltage $V_{\mathrm{o}}$ proportional to the absolute temperature $T$ is proposed. The linear relationship between $V$ and $T$ in the measurable temperature range of about $77-470 \mathrm{~K}$ is achieved using a commercial Si-pn diode. In this temperature-sensor the ac voltage change in the pn junction diode due to the temperature change is measured for a constant amplitude of superimposed ac small signal of current $\delta I$ on the constant forward dc current $I_{0}$. This sensor has merits that it can be calibrated at only one temperature point, that the output voltage is proportional to the absolute temperature $T$ and that the ac signal circuits can be isolated from dc bias voltage circuits. In addition, we have ascertained that a square wave as the superimposed ac signal of current $\delta I$ is superior to the sine wave because of easy connection to the digital circuits and easy measurement of the amplitude of the ac output voltage.
\end{abstract}

論 文

キーワード : 温度センサ, pn ダイオード, 半導体, $\mathrm{Si}$, 温度比例出力, 交流信号

Keywords : temperature-sensor, pn diode, semiconductor, $\mathrm{Si}$, proportional output to the temperature, AC signal

\section{1. はじめに}

センサの小型化，マイクロコンピュータの高性能化に伴 い，複数の機能を集積化したセンサデバイスの研究が行わ れている(1) (3)。センサネットワークのノードとして作用し, 温度や磁場など周囲の物理量を計測するセンサを有し，更 に GPS 電波の受信，他のノードと情報交換するためのマイ クロ波回路などを高密度に実装したセンサデバイスが提案 されている(3)。また，MEMS 技術を用いて形成された微小 なミラーを振動させ, 光信号のパターンを変化させ情報を 伝える方法が提案されており ${ }^{(4)}$, ワイヤレスであればノード の自由な配置が可能である。この超小型センサデバイスを 空中に浮遊させ, その一帯の物理情報に関して, 空間分解 能の高いセンシングデータが得られ，これまで見落とされ ていた局部的な変化まで捉えようとする提案もある(3)(5)(6)。 医療分野では, ワイヤレス動作可能な小型観測器を体内に 直接投入して診察する試みがなされており (7), 患者の負担を 減らすため小型化し, 詳細な情報を取得して高度な医療を 実現するために，より高機能化したセンサが求められてい る。

上述のような物理情報収集においては，温度は基本的な 物理量であり，他の物理量を変化させる要因となることが

\footnotetext{
東北学院大学 工学部

T985-8537 宮城県多賀城市中央 1 丁目 13-1

Department of Electronics, Tohoku Gakuin University

1-13-1, chuo, Tagajo, Miyagi 985-8537
}

多いので，センシング対象として，その計測が不可欠であ る場合が多い。

温度センサとして従来から知られているものには, サー ミスタやサーモダイオードなどがある。サーミスタは温度 によって抵抗值が大きく変化するので, 感度は良い反面,

一種類の素子で測定できる温度範囲が狭く, その温度特性 が直線とならない。また, 従来の一般のサーミス夕は焼結 体であることから特性のバラツキが大きく, 更に, 半導体 基板に集積化する製造技術，特に，CMOS 技術との適合性 が悪いという問題がある。

Fig. 1 に示した測定した市販の Si-pn 接合ダイオードの順

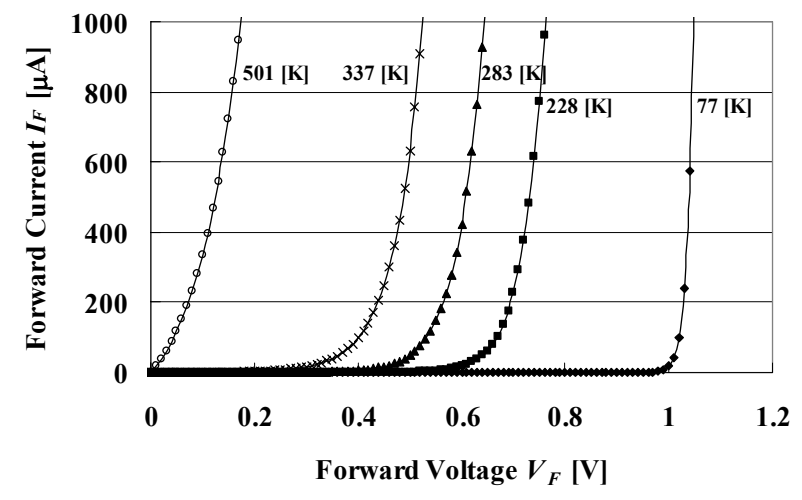

Fig. 1. $I_{F}-V_{F}$ characteristics of a commercial Si pn junction diode for various ambient temperatures. 
方向電圧 $V_{F}$ 一電流 $I_{F}$ 特性では, 低温側と比較して高温側で は小さな電圧でも大きい電流が流れるようになる。従来の サーモダイオードでは, この特性を利用し, ダイオードに 流す順方向電流 $I_{F}$ を一定に保ち, その時のダイオードに加 わる順方向電圧 $V_{F}$ が絶対温度 $T$ に関係することを利用した ものである。温度 $T$ に対する順方向電圧 $V_{F}$ 特性は, 不純物 が全てイオン化している範囲内では直線で表される。しか し, 切片を有する直線であり, かつ, 傾きが負であるため に得られた電圧をそのまま直接温度として表すことができ ない。また，直流電圧を測定するため，信号を増幅するに は増幅回路でのオフセット調整が必要になる ${ }^{(8)}$ 。

ここで，サーモダイオードの特性を表す式を導き，順方 向電圧 $V_{F}$ が絶対温度 $T$ の 1 次関数で表され, 切片を持つこ とを示す。ダイオードを流れる順方向電流 $I$ は, $q V \gg n k T$ の 場合，近似して(1)式のように表される ${ }^{(9)}$ 。

$$
I=I_{s}(T)\left\{\operatorname{Exp}\left(\frac{q V_{F}}{n k T}\right)-1\right\} \approx I_{s}(T) \operatorname{Exp}\left(\frac{q V_{F}}{n k T}\right) .
$$

(1)式を基に，お互いに不純物濃度が高い pn 接合の場合 を仮定して, 拡散電位 $V_{d}$ を使って表した式を導くと $(2)$ 式 となる。

$$
I=I_{\infty} \operatorname{Exp}\left(\frac{q\left(V_{F}-V_{d}\right)}{n k T}\right)
$$

ここに, $n:$ 理想係数, $k$ : ボルツマン係数, $q$ : 電 荷素量, $I_{s}$ : 逆方向飽和電流, $I_{\infty}: T=\infty$ とした場 合のダイオード電流, $V_{d}$ : 等価的な拡散電位, $T$ : 絶対温度

(2)式を, 順方向電圧 $V_{F}$ を求める形に変形すると $(3)$ 式と なる。

$$
V_{F}=V_{d}-\frac{n k T}{q} \ln \frac{I_{\infty}}{I}
$$

ここでは, 等価的な拡散電位 $V_{d}$ の温度変化は, ダイオー ド電流の指数関数的な温度依存性に対して無視している。 高濃度不純物同士の pn 接合ダイオードの場合は, 特に無視 できるほど小さい。このため( 3 )式は, 絶対温度 $T$ のみのた め 1 次関数の形で表すことができる。これをグラフに表す

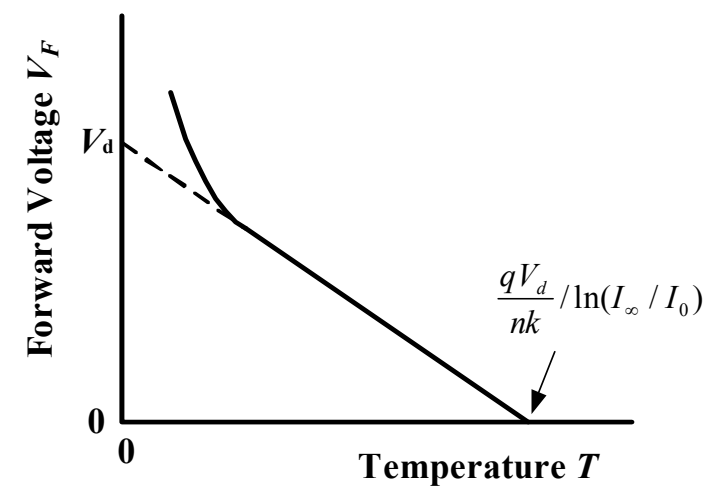

Fig. 2. Ideal forward voltage $V_{F}-$ temperature $T$ characteristics in a traditional thermodiode.
と Fig. 2 のようになる。上記の 2 種類のセンサでは式上での 未知数が 2 つあるため最低でも 2 点で温度校正をする必要 がある。

これに対し, 我々の提案する温度センサは, 1 個のダイオ ードを用いて, 77-470 K の広い温度範囲にわたって絶対温 度に比例した出力が得られるため, 増幅度を調整すれば温 度を直読みすることができ, 校正する場合には 1 点のみで よいという結果になる。例えば, 室温 $300 \mathrm{~K}$ の時に出力を $300 \mathrm{mV}$ になるように 1 点で校正すれば絶対温度測定が可能 になる。また, 得られた值から, OP アンプなどを利用して $273 \mathrm{mV}$ 分を減算することで ${ }^{\circ} \mathrm{C}$ 表示することも可能である。 また, 出力信号が交流であり, 直流成分であるオフセット 電圧の影響を受けないことからオフセット調整の必要がな い。

よって, サーミスタのような高い感度は持たないが，簡 単に構成の簡便な温度センサが得られる。また, 単純な pn 接合やショットキ接合ダイオードでよいため小型化可能で あり，MEMS 技術により形成された薄膜上の極めて小さな 場所の温度測定にも適用できる。

センサネットワークを構成するにあたって, 利便性のた めにワイヤレス化が必須であり, バッテリ動作させるため 低消費電力である必要がある。このためには, センサダイ オードの超小型化により, マイクロアンペア程度の電流で 必要とする電流密度を達成し, 測定時のみ電流を流寸間久 動作をさせることで低消費電力化可能である。Si であれば IC 化可能で CMOS の製造技術と完全に適合するため, 増幅 回路, 他の種類のセンサと集積化可能であり, 低消費電力 化によるバッテリサイズの削減と併せてデバイスの小型化 に貢献できる。

\section{2. 原理}

ダイオードを流れる近似した順方向電流 $I_{F}$ を表す(1)式 を $V_{F}$ で微分し, $T$ を求める式に変形すると, $(4)$ 式となる。 ここで, $d I_{F}$ を微小交流電流 $\Delta I, d V_{F}$ を微小交流電圧 $\Delta V$, 直 流電流 $I_{F}$ を一定值 $I_{0}$ とする。

$$
T=\frac{q}{n k} I_{0} \frac{\Delta V}{\Delta I}
$$

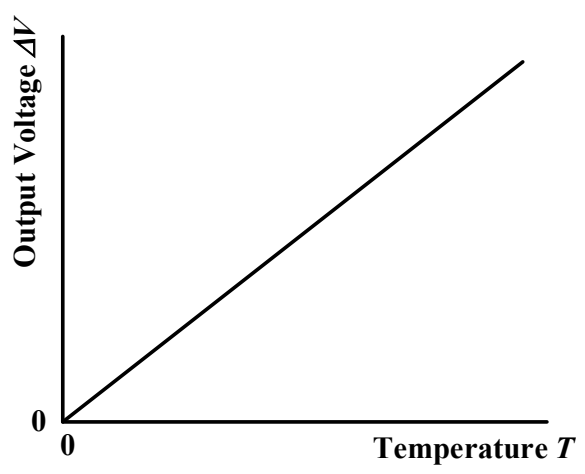

Fig. 3. Expected temperature $T$ - output voltage $\Delta V$ characteristics. 
(4)式では $\Delta I, \Delta V$ 以外は定数となり, 我々の提案した測 定方法(10)では(4)式を， $\Delta I$ を測定して $T \propto 1 / \Delta I$ と表される もの， $\Delta V$ を測定して $T \propto \Delta V$ と表されるものの 2 種類に展 開できるが，本論文では，絶対温度に比例した出力電圧が 得られ，この出力電圧から温度が直読みできる簡便である ことを特長とするため, $\Delta V$ を測定するものについてのみ述 ベる。

この方法では, $\delta I$ を重畳する一定振幅の交流電流， $\Delta V$ を 測定するダイオードの端子間に現れる交流出力電圧とする と, $\Delta V$ 以外は定数となるため係数 $\alpha$ とおくと (5)式のよう になる。

$$
\begin{aligned}
T= & \frac{q}{n k} \frac{I_{0}}{\delta I} \Delta V=\alpha \Delta V, \ldots \ldots \ldots . . . . . \\
& \text { ここで } \quad \alpha=\frac{q}{n k} \frac{I_{0}}{\delta I} .
\end{aligned}
$$

この式より温度 $T$ は $\Delta V$ のみの関数で, $\Delta V$ を測定するこ とで温度が求まることになり, Fig. 3 のような温度特性が予 想される。未定係数が $\alpha$ の 1 つのみで, 温度特性が原点から 延びるため, ダイオードの種類やばらつきに依らず任意の 1 点のみで校正可能である。

\section{3. 測定方法}

〈3.1〉 正弦波の重畳電流 $\delta /$ の場合 特別なダイオー ドは必要ないため市販の普通の小信号用 $\mathrm{Si}$ ダイオードを使 用し理論の検証を行った。ダイオードに順バイアスを加え ると Fig. 4 に示すような $I-V$ 特性が得られる。ここで, ダイ オードに一定の直流バイアス電流 $I_{0}$ を流し，そこに一定の 交流電流 $\delta I$ を重畳する。この時にダイオードの端子間に現 れる交流電圧 $\Delta V$ を測定する。

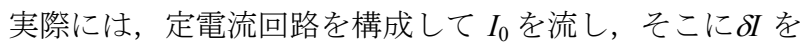
重畳させる。ダイオードに現れた $\Delta V$ のみを OP アンプのオ フセット電圧が無視できる程度に増幅した後, 交流信号の 振幅をピークーピークホールド回路を用いて直流信号に変 換し出力電圧 $V_{0}$ として電圧計で測定する。この測定回路の ブロック図を Fig. 5 に示す。

直流バイアス電流 $I_{0}$ を変化させた場合の影響を見るため に $I_{0}=100 \mu \mathrm{A}, 500 \mu \mathrm{A}, 1000 \mu \mathrm{A}$ として，それぞれに $\delta I=10$ $\mu \mathrm{A}, 33 \mu \mathrm{A}, 33 \mu \mathrm{A}$ の $1 \mathrm{kHz}$ の交流信号を重畳する。交流信 号 $\delta I$ として, 原理的に基本波のみである正弦波を入力して 実験する。

\section{〈3-2〉 正弦波と矩形波の重畳電流 $\delta /$ の場合の比較}

Fig. 4 から分かるように, 我々の提案している温度センサ の測定方法では，交流信号を重畳して正のピークと負のピ ークの 2 点の電圧を検出しその差を出力としている。その ためここでは正弦波を重畳しピークーピーク值を求めてい た。しかし, 結果から言えば，2 点の電圧值が求まればよい ので，任意の波形で良いはずである。このため，正弦波を 用いた場合と同じ出力が得られることを確かめるため, 両 波形について同じ測定回路を使用し，信号波形以外の測定 条件を同じとして比較, 検証する。

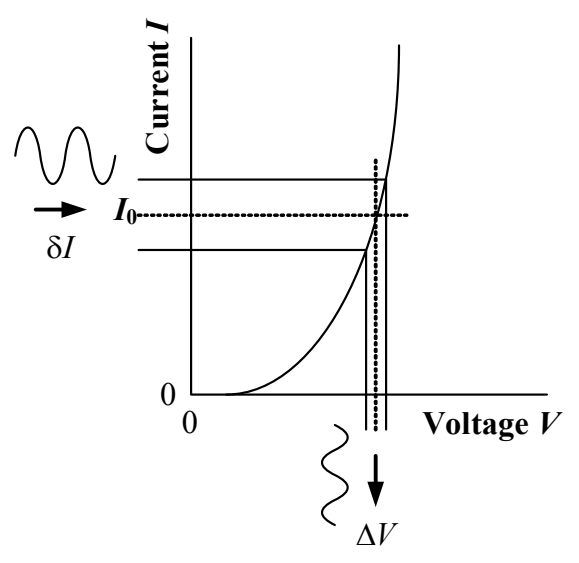

Fig. 4. Schematic diagram to explain the proposed method.

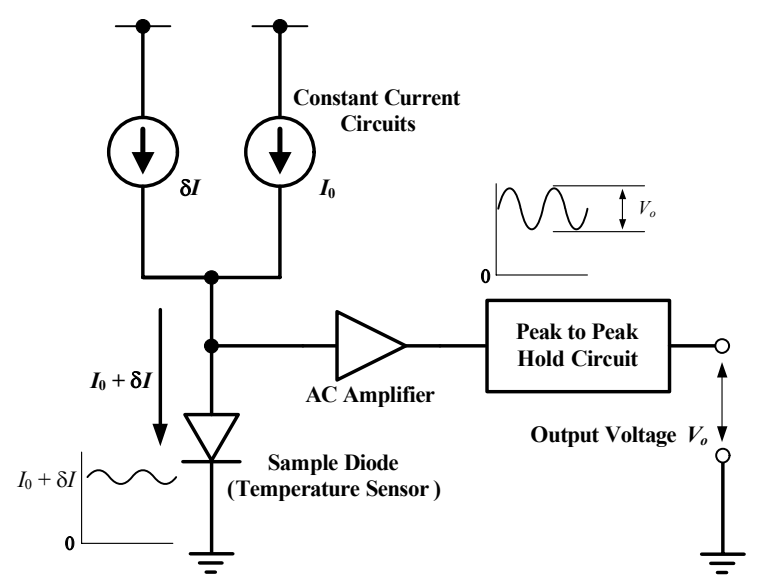

Fig. 5. Block diagram of the measurement circuits for the proposed method.

$\mathrm{A} / \mathrm{D}$ 変換する場合に, 重畳する交流電流 $\delta I$ が矩形波であ れば，変換が完了するまで同じ電圧值が一定期間保持され るため, 最大值が測定しやすくピークホールド回路などを 付加する必要がない。従って, 回路構成を簡単にすること ができ, デジタル回路との適合性が高く, 回路素子の削減 によって小型化できる。

また，矩形波の場合，正弦波のように発振回路を構成し て発振が安定するまで待つ必要がなく, 簡単に安定した直 流電圧を生成する方法が既に存在するため, これをチョッ ピングするだけで振幅の安定した入力信号が得られる。更 に, 単電源動作可能な回路を構成できるので, 瞬時に安定 した信号の生成が可能である。従って, センサの間欠動作 による省電力化が可能で, バッテリ容積の削減による小型 化にも貢献できる。

\section{4. 実験結果および考察}

〈4·1〉正弦波を重畳した場合正弦波を重畳して測 定した結果を Fig. 6 に示す。 $I_{0}=100 \mu \mathrm{A}$ では, 室温付近で傾 きが変化している部分があり, 原点から引いた直線に乗ら ず直線性も良くない。 $I_{0}=500 \mu \mathrm{A}, 1000 \mu \mathrm{A}$ では, 室温付近 での傾きの変化がほぼ無くなり, 原点から引いた直線に乗 


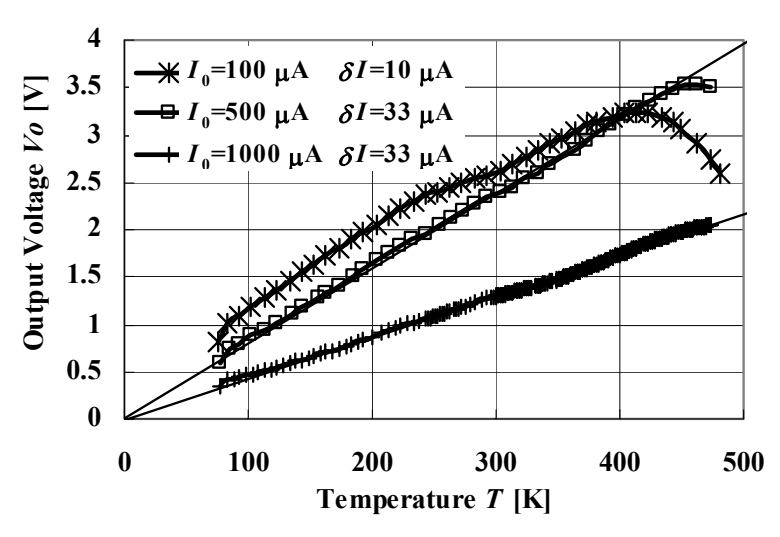

Fig. 6. Temperature $T$ - Output Voltage $V_{0}$ characteristics for various dc bias currents $I_{0}$.

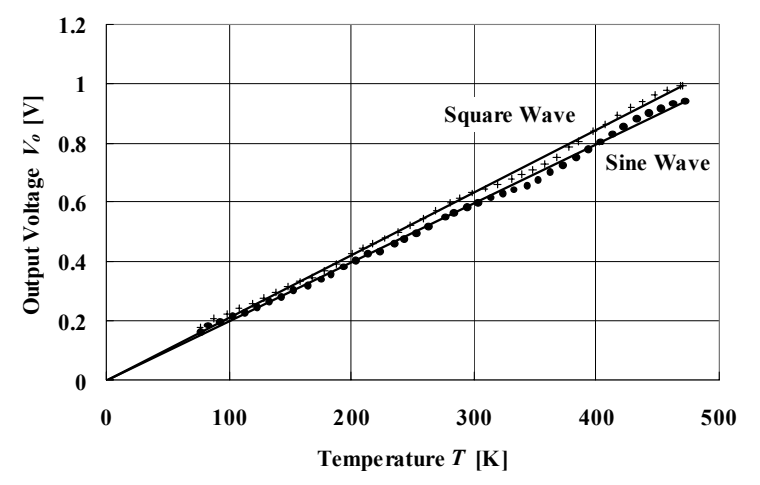

Fig. 7. Temperature $T$ - output voltage $V_{0}$ characteristics for a sine and a square wave as the superimposed signal $\delta I$.

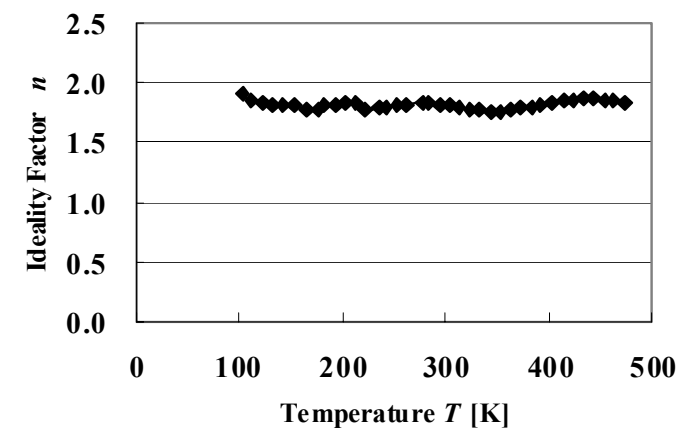

Fig. 8. Temperature dependence of the ideality factor $n$. (AC signal: Sine Wave)

っている。その他に, $I_{0}$ を大きくすることで高温領域での直 線性が改善され, 直線的に変化する範囲が広くなっている。 $I_{0}=500 \mu \mathrm{A}$ と $1000 \mu \mathrm{A}$ を比較すると, $500 \mu \mathrm{A}$ の方が 2 倍程 度の出力が得られている。これは， $I_{0}$ が $1 / 2$ になっているた めであり，(5)式から分かるように，どちらも $\delta I$ と, 測定 している温度 $T$ とが同じため, $I_{0}$ を変化させた場合には変数
は $\Delta V$ のみであり式の両辺が等しくなるには $\Delta V か ゙ 2$ 倍になる 必要があるためである。しかし, 実際の測定結果が 2 倍に 及んでいないが，これは，振幅が大きくなるほど単位時間 当たりの信号電圧の変化が大きくなり, Fig. 5 に示すピーク 一ピークホールド回路に使用しているホールドコンデンサ （図は省略）への充電が間に合わずに正弦波の最大值を短時 間で保持しきれなかったためと考えている。実際，ホール ドコンデンサの容量の大きさに出力電圧が依存することを 確かめている。Fig. 6 から, 直流バイアス電流 $I_{0}$ が小さいと きには, 高温側で傾きが変化し, 直線から外れる箇所が見 られるが, この小さな電流 $I_{0}$ では, 拡散電流に寄与するキ ヤリアが少ないので, バンドギャップを超えて励起される キャリアの増加が無視できないために, 真性領域に近づい たためであると考えている。そのため, $\mathrm{SiC}$ などのバンドギ ヤップの広い半導体材料を使ったダイオードであれば Si ダ イオードよりも高い温度領域まで測定することができる。 また, $I_{0}$ を大きくすることで, 高温まで直線的な特性の領域 が得られるのは, 注入されるキャリアが多くなったため, 励起されたキャリアの割合が相対的に小さくなり, 大きな 変化として現れなかったのだと考えている。

\section{〈4·2〉正弦波と矩形波を重畳した場合の比較}

Fig. 7 には, 一定の交流電流 $\delta I$ として, 微小の正弦波電流 と矩形波電流とを使用した場合のピークーピークホールド 回路の出力電圧 $V_{0}$ と絶対温度 $T$ との関係の実験結果を示し ている。なお, Fig. 6 に示寸正弦波を使用した場合の結果か ら, 直線性の良かった $I_{0}=1000 \mu \mathrm{A}$ とし, $\delta I=30 \mu \mathrm{A}$ とした。

Fig. 7 に示した結果から, 矩形波でも原点から引いた直線 上に乗ることが確認できた。しかし，条件が同じであるの に正弦波よりも矩形波を入力信号とした場合の方が, 出力 が大きく差が生じている。これは，〈4・1〉節で述べたよう にピークーピークホールド回路で振幅を測定しているた め, 正弦波は出力が常に変化するため最大值を保持するこ とが困難であるが，矩形波であれば同じ電圧值が一定期間 保持されるため, ピークホールド回路のホールドコンデン サ（実験では，同一の $1 \mu \mathrm{F}$ のコンデンサを使用した）への 充電期間が十分確保できたのだと考えている。従って, 矩 形波であれば回路の面から見ても最大值を保持しや寸く, 容易に測定が可能である。

Fig. 7 で正弦波を用いた場合の特性から求めた理想係数 $n$ をFig. 8 に示す。理論で温度 $T$ を表す式を導出する仮定にお いて, $n$ を含む式を使用しているが, 我々の提案では $n$ が温 度によらず一定という仮定の下で温度に対する出力特性が 原点から引いた直線で表すことができるとしていた。実験 結果から, 市販の Si pn 接合ダイオードで, ほぼ $100 \mathrm{~K}$ から $320 \mathrm{~K}$ の範囲では $3 \%$ 以内, $77 \mathrm{~K}$ から $470 \mathrm{~K}$ の測定を行った 全範囲では $6 \%$ 以内の誤差で簡便な温度計測ができること が確認できた。また, Fig. 8 に示すように, 実際に測定值か ら求めた $n$ が温度によらずほぼ一定の值を示すことが確認 できた。このことからも, 我々の仮定が成り立つと考えて いる。 


\section{6. 結 論}

交流信号重畳型のダイオード温度センサを提案して，理 論通り, 出力電圧が完全に絶対温度に比例して原点からの 直線的な特性が得られることを確認した。直流バイアス電 流 $I_{0}$ を大きくすることで, 計測温度範囲での直線性を改善 でき, $I_{0}=1000 \mu \mathrm{A}, \delta I=30 \mu \mathrm{A}$ の時には, $77 \mathrm{~K} \sim 470 \mathrm{~K}$ まで の広い範囲で誤差が $6 \%$ 以内の直線的な特性が得られ，100 $\mathrm{K}$ 程度から $320 \mathrm{~K}$ の範囲での誤差は 3\%であり非常に直線性 の良い特性が得られた。従って, $0 \mathrm{~K}$ から伸びる 1 次関数の 形で表すことができ， 1 点校正が可能である。しかし， $I_{0}$ が 小さい場合などには直線性の悪い箇所が存在するため, こ れらの原因については今後検討する必要がある。

センサネットワークでは屋外での使用が想定され，太陽 電池と従来のバッテリと比べて寿命が長いコンデンサを組 み合わせた電源が理想であるが，本センサは矩形波による 間欠動作ができ極めて省エネ型にできるため, 容量の小さ いコンデンサであっても十分動作が可能である。また，医 療分野では体内に埋め込んで使用されることが想定され， バッテリの交換など患者の負担を避けるため永久的に発電 できる温度差を使って発電する方式などが最適であるが, 電力容量が小さいという問題があるため, このように低消 費電力化が必要な用途にも応用可能である。

本実験では，ダイオードとして pn 接合ダイオードのみ扱 つたが，理論的には，ショットキ接合ダイオードでも同一 の(5)式が得られる。したがって, ダイヤモンドや酸化亜鉛 ( $\mathrm{ZnO})$ などのようにバンドギャップが大きく, p 型と $\mathrm{n}$ 型 の双方が未だ得られていないか, または, 製作が困難な半 導体でも，ショットキ接合が形成できれば，上述の簡易温 度センサが達成されることになる。したがって, これらの ワイドバンドギャップ半導体のショットキ接合ダイオード の使用により，更に高温までの簡易温度センサが達成され ると考えている。

(平成 18 年 12 月 28 日受付, 平成 19 年 3 月 1 日再受付)

\section{文献}

(1) R. X. Gao and Z. Fan : "Architectural design of a sensory node controller for optimized energy utilization in sensor networks", IEEE Trans. instrume \& measure, Vol.55, No.2 (2006-4)
(2) A. J. Skinner and M. F. Lambert : "Using Smart Sensor Strings for Continuous Monitoring of Temperature Stratification in Large Water Bodies", IEEE Sensors Journal, Vol.6, No.6 (2006-12)

(3) 安藤 繁・田村陽介・ 戸辺義人・南 正輝:「センサネットワーク技 術 ユビキタス情報環境の構築に向けて」, 東京電機大学出版局, pp.41-186 (2005)

(4) P. B. Chu, N. R. Lo, E. Berg, and K. S. J Pister : "Optical Communication Using Micro Corner Cuber Reflectors”, MEMS 97, Nagoya, Japan, 26-30 pp.350-5 (1997-1)

(5) K. C. Clarke : "Geocomputation's future at the extremes high performance computing and nanoclients", Parallel Computing Vol.29 pp.1281-1295 (2003)

(6) J. L. Hill and D. E. Culler : "Mica : A wireless platform for deeply embeded networks", IEEE Micro., Vol.22, No.6, pp.12-24 (2002-11/12)

( 7 ) K. Saito, H. Hashimoto, S. Endo, Y. Ueda, H. Mizuno, M. Kudo, and A. Uchiyama : "Telemetry Capsule for Gastric pH Monitoring", The Society of Instrument and Control Engineers, Vol.31, No.6, pp.699-704 (1995) (in Japanese)

斉藤恵一・橋本 洋 ・ 遠藤伸悟 ・植田康弘 ・水野 均 工藤正宏 . 内山明彦:「胃内 $\mathrm{pH}$ モニタ用テレメータカプセル」, 計測自動制御 学会論文集, 31，6，pp.699-704 (1995)

(8) G. C. M. Meijer and A. W. Herwaarden (Editors) : "Thermal Sensors", Institute of Physics Publishing, pp.116-120 (1994)

(9) M. Kimura and K. Toshima : "Thermistor-like pn junction temperature-Sensor with variable sensitivity and its combination with a micro-air-bridge heater", Sensors and Actuators, A108, pp.239-243 (2003)

(10) N. Takashima and M. Kimura : "Pn junction Temperature-Sensor by Use of Superimposed AC Signal", Proceedings of The 23rd Sensor Symposium, pp.253-256 (2006)

高 嶋 徳 明 (学生員) 1984 年 3 月 9 日生。2006 年 3 月東

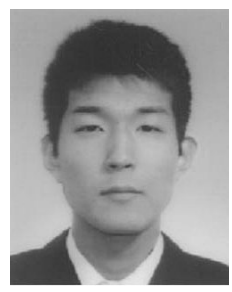
北学院大学工学部電気情報工学科卒業。現在, 同大学大学院工学研究科博士前期課程在籍。

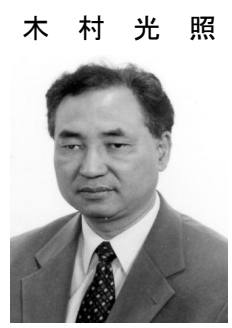

（正員） 1942 年 11 月 14 日生。1967 年 3 月電 気通信大学卒業, 1969 年および 1974 年 3 月東 北大学大学院修士課程および博士課程修了。工 学博士。1974 年 4 月から東北学院大学工学部電 気工学に講師として勤務, 1988 年 4 月より同教 授, 現在, 名称変更により同電気情報工学科教 授。1986 年 8 月から 87 年 3 月までカリフォル ニア大学バークレイ校客員教授。現在, 半導体 デバイス, 特に, 各種センサの開発研究に従事。応用物理学会, 電 子情報通信学会, 日本応用磁気学会, IEEE の会員。 